\title{
Inadequate Nitrogen Fertilization: Main Cause of the Low Seed Yield on the Chia Crop (Salvia hispanica L.)
}

\author{
Anacleto Sosa-Baldivia ${ }^{1 *}$ and Guadalupe Ruiz Ibarra ${ }^{2}$ \\ ${ }^{1}$ Nutrilite-Amway, El Petacal, Jalisco Mexico \\ ${ }_{2}^{2}$ Instituto Tecnológico José Mario Molina Pasquely Henriquez, Tamazula de Gordiano Jalisco, México
}

Received: January 12, 2018; Published: January 18, 2018

*Corresponding author: Anacleto Sosa Baldivia, Avenida Mexico \#8, El Petacal Jalisco, Mexico, CP 49750 , Tel: 0134141 17878;

Email: Anacleto.sosa@amway.com

\section{Introduction}

Chia (Salvia hispanica L.) is a Mexican ancestral crop that for its nutritional properties presents high demand in the international market, its growth rate is $239 \%$ annually and it is estimated that by 2020 its sales will be $\$ 1.2$ billion dollars [1]. Since 1917, it has been reported that the maximum attainable seed yield (SY) on chia is close to $3.0 \mathrm{t} \mathrm{ha}^{-1}$ [2-5]; however, the SY that the farmers commonly achieve in commercial plots is lower, and on average it only is 0.36 t ha ${ }^{-1}$ [6]. According to [7], the low productivity on chia due to their agronomic management has not been modernized, and to this date it still is cultivated mainly on rainy season, and the use of fertilizers, pesticides and improved varieties is scarce. The plasticity of the chia to adapt and produce under a low-input systems has led erroneously to assume that it presents low requirements of water and fertilizer [8,9], and also it resists the attack of pests and diseases [10].

Therefore, although its integration into the modern agriculture started since 1991, to this date is unknown how the production controllable factors (improved varieties, planting date irrigation, plant density, and other ones), and particularly the fertilization with macro and micronutrients affects their productivity. Regarding with the nitrogen fertilization, the consulted literature indicates that the higher nitrogen rate evaluated on chia is $45 \mathrm{~kg} \mathrm{ha}^{-1}$ [11]. If it is assumed that this specie take up $80 \%$ of this rate, and it produces $16.7 \mathrm{~kg}$ of seed per each $\mathrm{kg}$ of $\mathrm{N}$ absorbed, the maximum attainable SY could be $601 \mathrm{~kg} \mathrm{ha}^{-1}$.Considering that this value is consistent with the SY achieved at 1935 [12] when the nitrogen use was scarce [13], we developed the hypothesis that the inadequate nutrition could be the main cause because the SY on chia has not improved in the last 83 years. To confirm this assumption, during 2016-2017 we conducted two trials to evaluate the response of four chia varieties to different nitrogen rates.

The findings of both these studies showed that under of edaphoclimatic conditions of Toliman Jalisco, México, the productive potential of chia $\left(2.21 \mathrm{t} \mathrm{ha}^{-1}\right)$ is six times higher than the world average $\left(0.36 \mathrm{t} \mathrm{ha}^{-1}\right)$, and also, that it can be increased by using improved varieties combined with an adequate nitrogen fertilization [7]. The application of $100 \mathrm{~kg} \mathrm{~N}^{-1}$ along with the use of the experimental genotype G-39 (during 2018, Nutrilite Co. will patent this genotype with the name of "Rehnborg") allowed to obtain a SY of $2.21 \mathrm{t} \mathrm{ha}^{-1}$, and even, when the G-39 cultivar is established in an optimal sowing date, the SY is close to $3.0 \mathrm{t} \mathrm{ha}^{-1}$ [14]. These results differ that those reported in other parts of the world, because the most of them found no response of the chia crop to nitrogen application [15,16]. The study published by [7] is the first one where the response of the chia crop to nitrogen fertilization is based on the SY, and the results obtained clearly suggest that in order to improve the potential productive on chia, besides developing yielder cultivars, there should also be generated fertilization norms that ensure the adequate nutrition of this oilseed. Historically the nitrogen fertilization is the agronomic practice that has most helped to increase the crop yields $[13,17$ $20]$ and, according to our results we estimated that the nitrogen fertilization could help to raise on $63 \%$ the SY on chia.

\section{References}

1. Cassiday L (2017) Chia: superfood or superfat. INFORM 28(1): 6-13.

2. Lomanitz S (1917) Vegetable drying oil. Patent number, USA, 1: 244-521.

3. Yeboah S, Owusu DE, Lamptey LNJ, Mochiah MB, Lamptey S, et al. (2014) Influence of planting methods and density of performance of chia (Salvia hispanica L.) and its suitability as an oilseed plant. Agricultural Science 2(4): $14-26$

4. Ketthaisong D, Woravittayakit K, Lertrat K (2016) Growth and yield potential of chia Seed (Salvia hispanica L.) in Thailand.

5. Sosa BA, Ruiz-Ibarra G, Rana J, Gordillo-Sobrino G, West H, et al. (2017) Fecha de siembra: un método para evadir el ataque de Diabrotica speciosa Germar, 1824 (COLEOPTERA: CHRYSOMELIDAE) y aumentar el rendimiento de semilla en chía (Salvia hispanica L.). Entomología Mexicana 3: 277-284.

6. Peperkamp M (2015) CBI Tailored Intelligence: chia from Bolivia'a modern super seed in a classic pork cycle? CBI Ministry of Foreign Affairs. The Hague, Netherland, p. 16. 
7. Sosa BA, G Ruiz-Ibarra, G Gordillo-Sobrino, JD Etchevers-Barra, M Sharma, et al. (2017) Respuesta de Cuatro Cultivares de Chía (Salvia hispanica L.) a la Fertilización Nitrogenada en El Petacal Jalisco México. Informaciones Agronómicas de Hispanoamérica 28: 8-13.

8. Jamboonsri W, Phillips TD, Geneve LR, Cahill PJ, Hildebrand FD (2012) Extending the range of and ancient crop (Salvia hispanica L.) a new omega 3 source. Gen Resour Crop Evol 59(2): 171-178.

9. Orozco dRG, Duran PN, González EDR, Zaracúa VP, Ramírez OP, et al. (2014) Proyecciones de cambio climático y potencial productivo para Salvia hispanica L. en las zonas agrícolas de México. Rev Mex Sci Agric 10: 1831-1842.

10. Muñoz AL, Cobos A, Díaz O, Aguilera MJ (2013) Chia seed (Salvia hispanica): An ancient grain and a new functional food. Food Reviews International 29: 294-308.

11. Baginsky CJ, Arenas H, Escobar M, Garrido N, Valero D, et al. (2016) Growth and yield of chia (Salvia hispanica L.) in the Mediterranean and desert climates of Chile. Chilean Journal of Agricultural Research 76 (3): 255-264.

12. Rulfo JM (1937) La chía. Agricultura 1: 28-37.

13. Sutch RC (2008) Henry Agard Wallace, the Iowa corn yield tests, and the adoption of hybrid corn. Working Paper 14141. National Bureau of Economic Research.
14. Sosa-Baldivia A, Ruiz-Ibarra G, Gordillo-Sobrino G, West H, Sharma S, et al. (2017) Fecha de siembra: un método para evadir el ataque de Diabrotica speciosa Germar (Coleoptera: Chrysomelidae) y aumentar el rendimiento de semilla en chía (Salvia hispanica L.). Entomología Mexicana 4: 277-284

15. Bochicchio R, Rossi R, Labella R, Bitella G, Perniola M, et al. (2015) Effect of sowing density and nitrogen top-dress fertilization on growth and yield of chia (Salvia hispanica L.) in a Mediterranean environment: first results. Italian J Agron 10: 163-166.

16. Bilalis D, Tabaxi I, Zervas G, Tsiplakou E, Travlos I, et al. (2016) Chia (Salvia hispanica) fodder yield and quality as affected by sowing rates and organic fertilization. Commun Soil Sci Plant analysis 47(15): 17641770.

17. Collings GH (1958) Fertilizantes comerciales, sus fuentes y usos. Versión española traducida por Sánchez BE Salvat editores SA DF, México.

18. Bell MA, Fischer RA, Byerlee D, Sayre K (1995) Genetic and agronomic contributions to yield gains: A case study for wheat. Field Crops Research 44(2-3): 55-65.

19. Roberts TL (2009) the role of fertilizer in growing the world's food. Better Crops 9(2): 12-15.

20. Sosa BA, Ruiz-Ibarra (2017) La disponibilidad de alimentos en México: un análisis de la producción agrícola de 35 años y su proyección para 2050. Papeles de Población 23(93): 20-230.

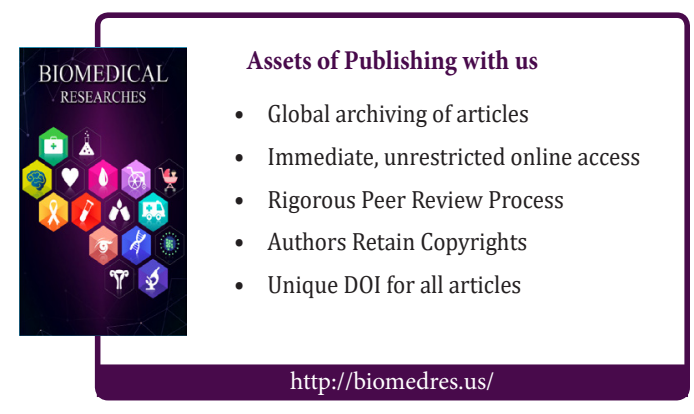

